\title{
Ornamental Grasses Show Minimal Response to Cultural Inputs
}

\author{
Mack Thetford ${ }^{1,4}$, Gary W. Knox ${ }^{2}$, and Edwin R. Duke ${ }^{3}$
}

AdDITIONAL INDEX wORDs. Fertilizer, irrigation, Tripsacum dactyloides, Evagrostis elliottii, Mublenbergia capillaris, Miscanthus sinensis, Schizachyrium scoparium, Panicum virgatum

SuMMARY. Full sun trial gardens were established at two sites in northern Florida. Six U.S. native and three non-native warm season grass species were evaluated in a split-plot design. Only eastern gamagrass (Tripsacum dactyloides), elliott's lovegrass (Eragrostis elliottii), gulf hairawn muhly (Mublenbergia capillaris), little bluestem (Schizachyrium scoparium), and 'Central Park' maiden grass (Miscanthus sinensis) showed a significant response to supplemental irrigation or fertilization. Supplemental irrigation did not influence foliage height for any of the grasses, whereas supplemental fertilization influenced foliage height only for chinese fountain grass (Pennisetum alopecuroides). The response differences between locations were attributed in part to soil types. This study observed minimal or no response of shoot growth to supplemental irrigation or fertilization for the grass species tested, thereby affirming the broad adaptability and minimal need for inputs for these ornamental landscape plants.

$\mathrm{O}$ rnamental grasses have been increasing in popularity for a number of years. These grasses originate from a wide range of habitats (Davidson and Gobin, 1998; Greenlee, 1992). The growth of grasses may be influenced greatly by the addition of water, and grasses such as gulf hairawn muhly or maiden grass need little or no supplemental irrigation once they are established (Thetford et al., 2009). Kochsiek et al. (2006) investigated the ecophysiological responses of little bluestem to both water and nitrogen in sandy soils of the Great Plains and concluded that little bluestem would likely respond positively to fertilization under moderate drought stress. They also concluded that little bluestem would also likely be able to take

This project supported in part by the Center for Cooperative Agricultural Programs, College of Engineering Sciences, Technology and Agriculture, 215 Perry-Paige Building South, FL A\&M University Tallahassee, FL 32307

Mention of a trademark, proprietary product, or vendor does not constitute a guarantee or warranty of the product by the Florida Agriculture Experiment Station and does not imply its approval to the exclusion of other products or vendors that also may be suitable.

${ }^{1}$ Associate Professor, Department of Environmental Horticulture, IFAS, University of Florida, 5988 Highway 90, Building 4900, Milton, FL 32583

${ }^{2}$ Professor, Department of Environmental Horticulture, IFAS, University of Florida, 155 Research Road, Quincy, FL 32351

${ }^{3}$ Associate Professor, Ornamental Horticulture, CESTA, FL A\&M University, 306 Perry Paige South, Tallahassee, FL 32306

${ }^{4}$ Corresponding author. E-mail: thetford@ufl.edu. advantage of increases in precipitation but a concurrent increase in fertilization would probably not provide any competitive advantage to this species. The challenge for the landscape manager is the need to strike a balance between adequate irrigation and fertility without over or under application. Although grasses may respond to supplemental irrigation and fertility with increased vigor and size, an excess of water and nutrients may produce weak foliage and inflorescences that will lodge (M. Thetford, unpublished). Information is needed to better understand the landscape performance of ornamental grasses under a variety of landscape management levels using both irrigation and organic and synthetic fertilizers.

The objectives of this work were to evaluate effects of supplemental irrigation and fertilization on the landscape performance of nine ornamental grasses and to determine if fertilizer formulation (organic vs. synthetic) affected plant growth.

\section{Materials and methods}

SITES. Full sun trial gardens were established at two sites in northern Florida: 1) Gadsden County (GC) [North Florida Research and Education Center, Quincy, FL; lat. $30^{\circ} 32.873$ 'N, long. $84^{\circ} 35.624^{\prime} \mathrm{W}$, elevation $245 \mathrm{ft}$; American Horticulture Society (AHS) Heat Zone 9, U.S. Department of Agriculture (USDA) Hardiness Zone $8 \mathrm{~b}$, Norfolk loamy fine sand (5\% to $8 \%$ slope, $2.59 \%$ organic matter, loamy fluviomarine deposits), $\mathrm{pH}$ 5.5] and 2) Santa Rosa County (SRC) [West Florida Research and Education Center, Jay, FL; lat. $31.0^{\circ} \mathrm{N}$, long. $87.2^{\circ} \mathrm{W}$, AHS Heat Zone 9, USDA Hardiness Zone 8 a, Orangeburg sandy loam $(2.1 \%$ organic matter, $1 \%$ slope, typic paleudults), $\mathrm{pH}$ 6.6]. The gardens contained landscape fabric covered rows to minimize weed growth.

SPECIES. Six U.S. native and three non-native warm season grass species or cultivars were evaluated. Species native to the United States included eastern gamagrass, elliott's lovegrass, gulf hairawn muhly, little bluestem, 'Prairie Sky' switchgrass (Panicum virgatum), and 'Rotstrahlbusch'red switchgrass (Panicum virgatum). The three non-native warm season grasses included 'Adagio' maiden grass (Miscanthus sinensis), 'Central Park' maiden grass (Miscanthus sinensis), and 'Hameln' chinese fountain grass. Liners of all species were obtained from commercial sources with the exception of eastern gamagrass which represented a single genotype collected from a population in Florida. All plants were finished in l-gal containers using milled pine bark and $\mathrm{l}$ tablespoon of $18 \mathrm{~N}-2.6 \mathrm{P}-9.9 \mathrm{~K}$ synthetic fertilizer (Osmocote, 8-9 month release; Scotts, Marysville, $\mathrm{OH}$ ).

Evaluation. In Spring 2005 (GC: 21 Apr. 2005, SRC: 13 May 2005), 18 plants of each of the nine species and cultivars growing in l-gal containers were transplanted to tilled

\begin{tabular}{llll}
\hline $\begin{array}{l}\text { Units } \\
\text { To convert U.S. to SI, } \\
\text { multiply by }\end{array}$ & U.S. unit & SI unit & $\begin{array}{l}\text { To convert SI to U.S., } \\
\text { multiply by }\end{array}$ \\
\hline 0.3048 & $\mathrm{ft}$ & $\mathrm{m}$ & 3.2808 \\
0.0929 & $\mathrm{ft}^{2}$ & $\mathrm{~m}^{2}$ & 10.7639 \\
3.7854 & gal & $\mathrm{L}$ & 0.2642 \\
2.54 & inch $(\mathrm{es})$ & $\mathrm{cm}$ & 0.3937 \\
4.8824 & $\mathrm{lb} / 1000 \mathrm{ft}^{2}$ & $\mathrm{~g} \cdot \mathrm{m}^{-2}$ & 0.2048 \\
28.3495 & $\mathrm{oz}$ & $\mathrm{g}$ & 0.0353 \\
14.7868 & tablespoon & $\mathrm{cm}^{3}$ & 0.0676 \\
$\left({ }^{\circ} \mathrm{F}-32\right) \div 1.8$ & ${ }^{\circ} \mathrm{F}$ & ${ }^{\circ} \mathrm{C}$ & $\left(1.8 \times{ }^{\circ} \mathrm{C}\right)+32$ \\
& & &
\end{tabular}


plots in a randomized complete block design with three replications in each evaluation garden. Plants were spaced $5 \mathrm{ft}$ apart within each row, with $6 \mathrm{ft}$ between rows. To aid establishment, all plants received a single application of 1 gal of water each week for 4 weeks post-transplant. Following winter dormancy plants were pruned to 6 inches on 15 Mar. 2006. The experimental design was a split plot with a factorial arrangement of treatments. There were two levels of irrigation and three levels of fertilization. The main effect of irrigation (two levels) was randomly assigned to $1 / 2$ of each plot (a single application of 1 gal per plant each week for half of the plots using a drip irrigation system and no supplemental irrigation for the remaining plots). Fertilizer treatments were randomly assigned within each irrigation plot and included no fertilizer, $18 \mathrm{~N}-2.6 \mathrm{P}-$ 9.9K synthetic fertilizer (Osmocote, $8-9$ month release) and $5 \mathrm{~N}-0.9 \mathrm{P}-$ $3.3 \mathrm{~K}$ organic fertilizer (Ecosential; Lesco, Cleveland, $\mathrm{OH}$ ). Fertilizers were applied within a 2 -ft-diameter circle to deliver rates equivalent to $6 \mathrm{lb} / 1000 \mathrm{ft}^{2}$ nitrogen per year. Synthetic fertilizer was applied once each spring (April) and organic fertilizer was split in two applications (April and July) to accommodate differences in nutrient solubility. This fertility level was based on providing adequate nitrogen fertility for high levels of maintenance and/or to stimulate growth (Knox et al., 2002). The nine grass species were randomly assigned to each of the irrigation/fertilization plots. Fire ant (Solenopsis spp.) control was achieved with applications of granular ant bait (Hydramethylnon; BASF Australia, Baulkham Hills, Australia), and weeds between plots were managed with glyphosate. No pesticides were applied within the plots and weeds were removed by hand weeding as needed.

Each October foliage and inflorescence height (from soil level), foliage width (widest point), and basal width at ground level were measured (all in centimeters). Foliage and basal widths represent the average of two measurements per plant (the widest point and width perpendicular to the widest point). An overall visual rating was also applied each summer to assess observed visual quality: $(5=$ exceptionalpremium color and form, extremely healthy and vigorous; $4=\operatorname{good}-$ good quality, very acceptable, minor flaws, nice color without yellowing, good form, healthy and vigorous; 3 = fair-marginally acceptable, somewhat desirable form and color, moderately healthy; 2 = poor-not acceptable, sparse/uneven form, severe leaf necrosis or yellowing, unhealthy appearance; 1 = not acceptable - plant dead or nearly so with unhealthy appearance). The experiment continued for two growing seasons (18 months).

Daily rainfall and mean maximum and minimum temperatures data were recorded by the Florida Automated Weather Network monitoring stations at the sites in GC (lat. $30^{\circ} 32.749^{\prime} \mathrm{N}$, long. $84^{\circ} 35.939^{\prime} \mathrm{W}$ ) and in SRC (lat. $30^{\circ} 47.0^{\prime} \mathrm{N}$, long. $87^{\circ} 13.0^{\prime} \mathrm{W}$ ).

Data were analyzed using mixed model methods. The random effects were blocks-within-sites. The fixed effects were sites. Means were separated using least squares means (with PDIFF option) as part of the mixed model analyses in SAS (version 8.01; SAS Institute, Cary, NC). Probability values were adjusted using the Bonferroni method. Strong effects of location and year were evident hence each location and year were treated as separate experiments and analyzed for effects of irrigation and fertilization. Significant differences and accompanying means are presented only in the text when practical or are presented in table format along with probability values where significant interactions were present among main effects. Where significant differences are noted without accompanying probability values significance was confirmed at or below an alpha level of $5 \%$.

\section{Results and discussion}

RaINfall. Mean monthly rainfall for both sites was generally below the 30-year normal (1971-2000) for most months of the experimental period (Fig. 1). There were only 6 months where rainfall met or exceeded normal for SRC and 8 months where rainfall met or exceeded normal for GC. Overall mean maximum temperatures for the trial period were generally higher than normal, whereas mean minimum temperatures were generally lower than normal (Fig. 2).

On the basis of significant responses of measured growth parameters (foliage height, foliage width, basal area, flower height) supplemental irrigation and fertilization influenced plant growth for five of the nine species tested. Details of landscape performance, including plant survival and visual quality ratings are detailed below for each species.

Eastern gamagrass is a bunch grass native to the eastern United States and is best adapted to wet habitats (Henson and Fenchel, 2007). All plants survived the trial period (Tables 1 and 2). For plants in GC foliage height was greater with supplemental irrigation but only at the end of the first growing season. Although basal area was similar for the two sites by year 2, GC basal area for plants fertilized with organic fertilizer was smaller than those fertilized with synthetic fertilizers in year 1 . Eastern gamagrass performed well as a landscape plant both with and without supplemental irrigation and maintained an above average visual rating score (4.6) indicating high quality, healthy plants with good form and color regardless of fertilizer or irrigation treatment. The occasional inflorescences reached an average height of $84 \mathrm{~cm}$ although flowering was not consistent for this species with plants in SRC producing inflorescences both years ( $56 \%$ in $2005,39 \%$ in 2006 ) and plants in GC producing inflorescences only in $2005(89 \%)$.

Survival of elliott's lovegrass averaged 95\% (SRC) and 100\% (GC) in 2006 and plants generally increased in size in GC over time, whereas plant size in SRC decreased (Table 1). Supplemental irrigation influenced foliage height and flower heights in 2005. In GC, both foliage heights and flower heights were greater with supplemental irrigation in 2005, whereas no differences were evident by 2006 . In SRC, foliage height was influenced both by irrigation and fertilizer source where no differences in foliage height were evident among plants receiving supplemental irrigation and without supplemental irrigation; fertilization with organic fertilizer $(95 \mathrm{~cm})$ resulted in taller plants compared with plants fertilized with synthetic fertilizer $(74$ $\mathrm{cm})$. Foliage height of nonfertilized, nonirrigated plants $(84 \mathrm{~cm})$ did not differ from height of nonirrigated plants receiving supplemental fertilizer $(68 \mathrm{~cm})$. Foliage width and flower heights were greater for nonirrigated plants in 2005, whereas no differences were evident in 2006.

Visual ratings reflected the differences in plant height and width and 


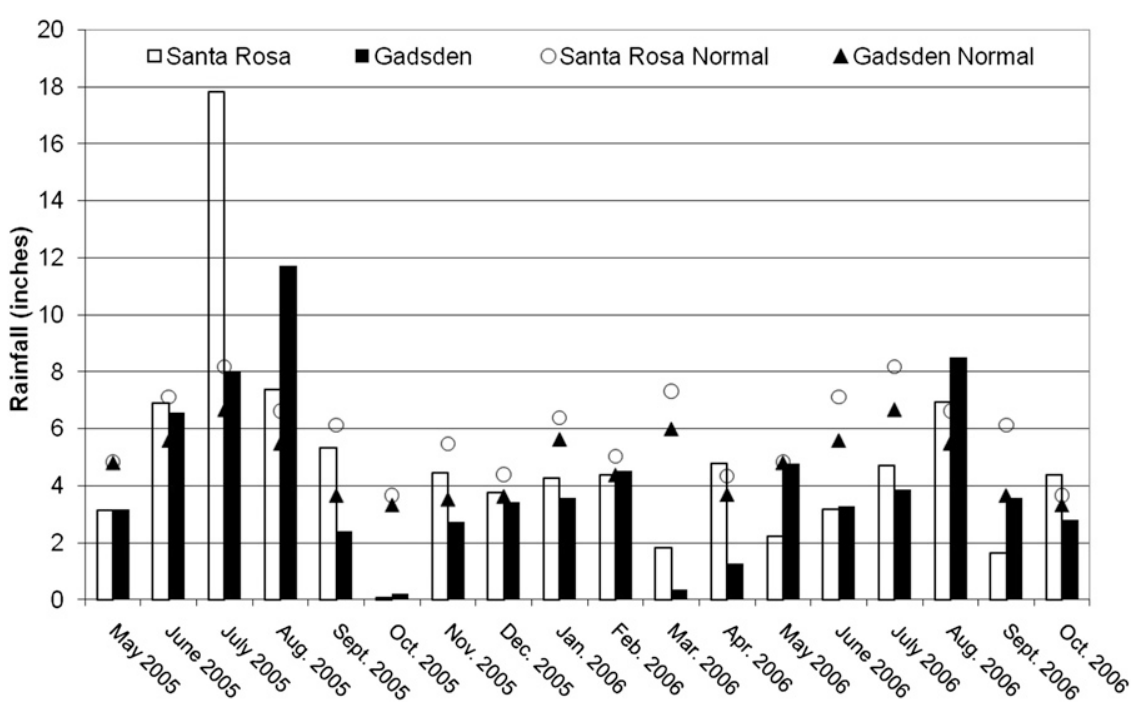

Fig. 1. Monthly rainfall (inches) from May 2005 to Oct. 2006 (bars) and monthly rainfall 30-year normals (1971-2000) (symbols) at the North Florida Research and Education Center, Quincy, FL (Gadsden County) and the West Florida Research and Education Center, Jay, FL (Santa Rosa County); 1 inch $=2.54 \mathrm{~cm}$.

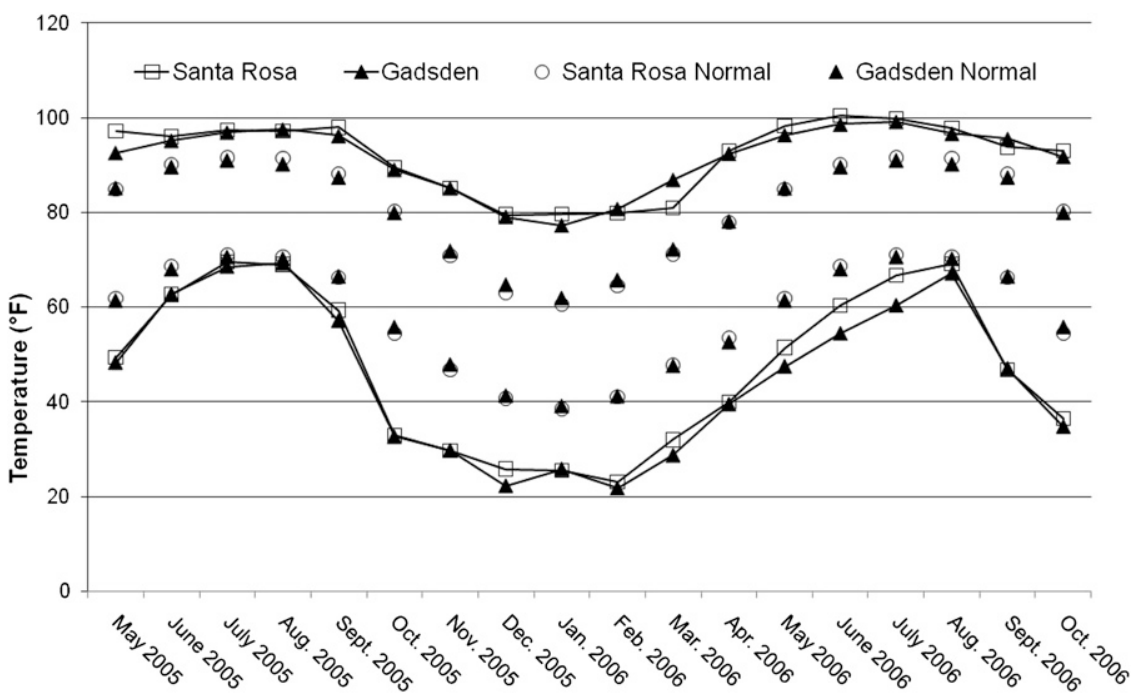

Fig. 2. Monthly maximum and minimum air temperatures from May 2005 to Oct. 2006 and monthly maximum and minimum air temperature 30 -year normals (1971-2000) at the North Florida Research and Education Center, Quincy, FL (Gadsden County) and the West Florida Research and Education Center, Jay, FL (Santa Rosa County); $\left({ }^{\circ} \mathrm{F}-32\right) \div 1.8={ }^{\circ} \mathrm{C}$.

suggest plants in SRC performed best in 2005 with a rating of exceptional (4.9), but quality declined to good by 2006 (3.4) similar to ratings of plants in GC (3.3) (data not shown). Gann et al. (2008) described elliot's lovegrass as a species occurring on moist to wet, well-drained or occasionally inundated freshwater or brackish soils and noted the species has low nutritional requirements and grows in nutrient poor soils. These results suggest that despite widespread occurrence of this species, particularly in
'Hameln' chinese fountain grass did not survive both seasons of the trial, concurring with other Florida studies (Thetford et al., 2009; Wilson and Knox, 2009). Overall survival decreased from $89 \%$ in 2005 to only a single surviving plant by 2006 (data not shown). By the end of 2005 , foliage height averaged $22 \mathrm{~cm}$, basal area $0.07 \mathrm{~m}^{2}$, and foliage width 49 $\mathrm{cm}$. All surviving plants flowered in 2005 and the mean flower height averaged $45 \mathrm{~cm}$. Visual ratings were higher in SRC than GC at the end of 2005 because several plants had died and were not considered in the visual ratings (data not shown). Survival in SRC averaged $83 \%$ with a visual rating of 3.7 , whereas survival in GC averaged $94 \%$ with a visual rating of 2.1 . Wilson and Knox (2009) noted that visual quality of chinese fountain grass and its cultivars generally declined in October without resuming growth through May. This species has consistently performed well for only a single growing season in northern Florida (Wilson and Knox, 2009) and has been recommended as a short-term perennial for low-input landscapes (Thetford et al., 2009). Neither fertilization and/or irrigation at the rates within this trial could overcome the consistent mortality occurring after the first growing season.

Gulf hairawn muhly survival averaged 93\% overall although some plants died at both sites within both irrigated and nonirrigated plots $(\mathrm{Ta}-$ ble 1). By 2006, survival for plants in SRC receiving supplemental irrigation $(78 \%)$ was lower than survival of nonirrigated treatments $(89 \%$ to $100 \%)$. Gulf hairawn muhly is a facultative upland plant in the southeastern United States usually occurring in nonwetlands (estimated probability $67 \%$ to $99 \%$ ), but occasionally found on wetlands (estimated probability $1 \%$ to 33\%) (Kirk and Belt, 2010). Survival in the present trial was similar to work of Robinson and Schultz (1994) who achieved 85\% survival in parking lot plantings after a 6-month establishment period where plants were watered weekly.

Plants in SRC showed a greater foliage width in response to addition of organic fertilizer in 2005, but an interaction of irrigation and fertilizer effects was evident for foliage height, basal area, and flower height (Table 1). Basal area increased to a mean of 


\section{Research Reports}

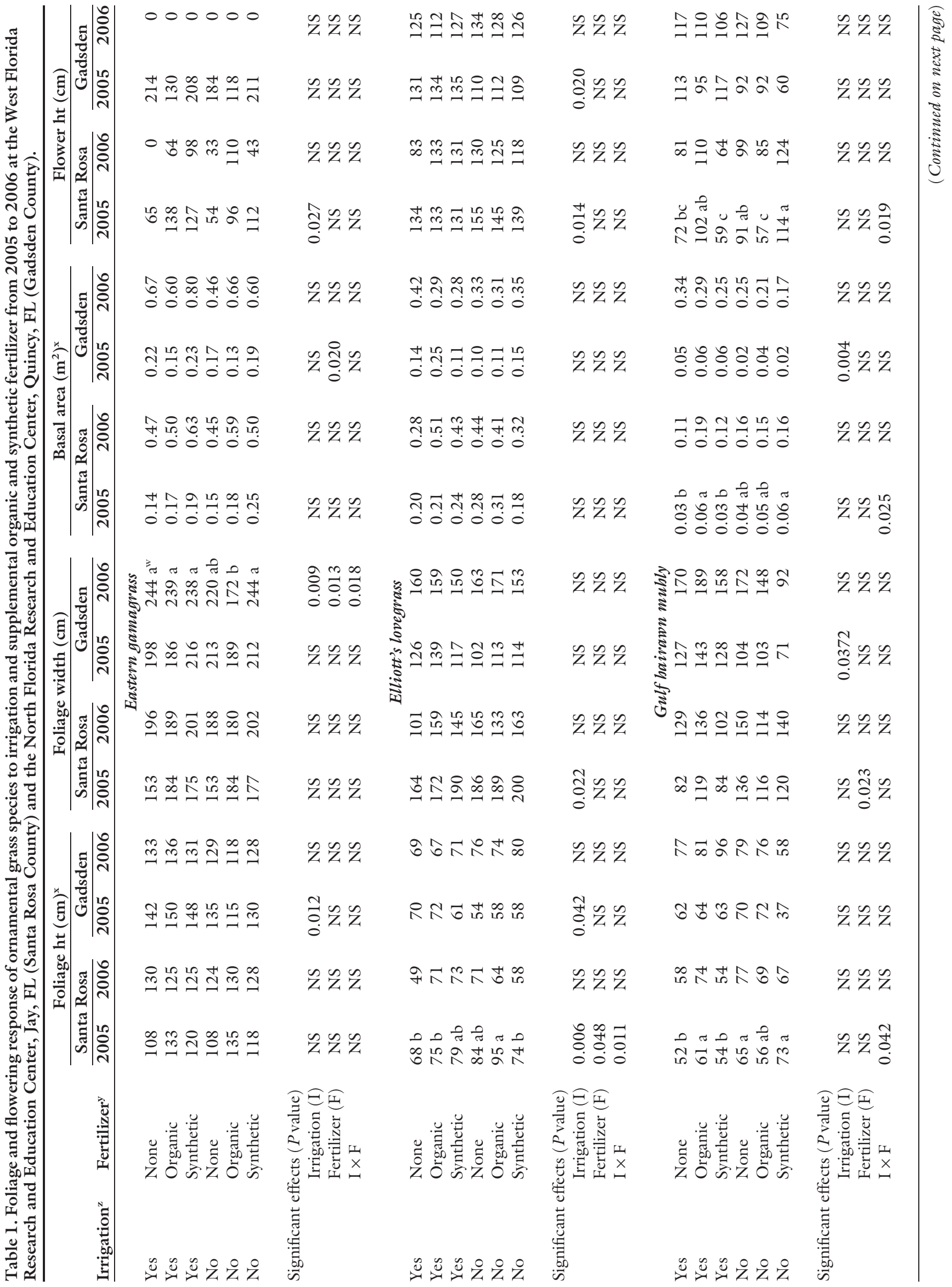




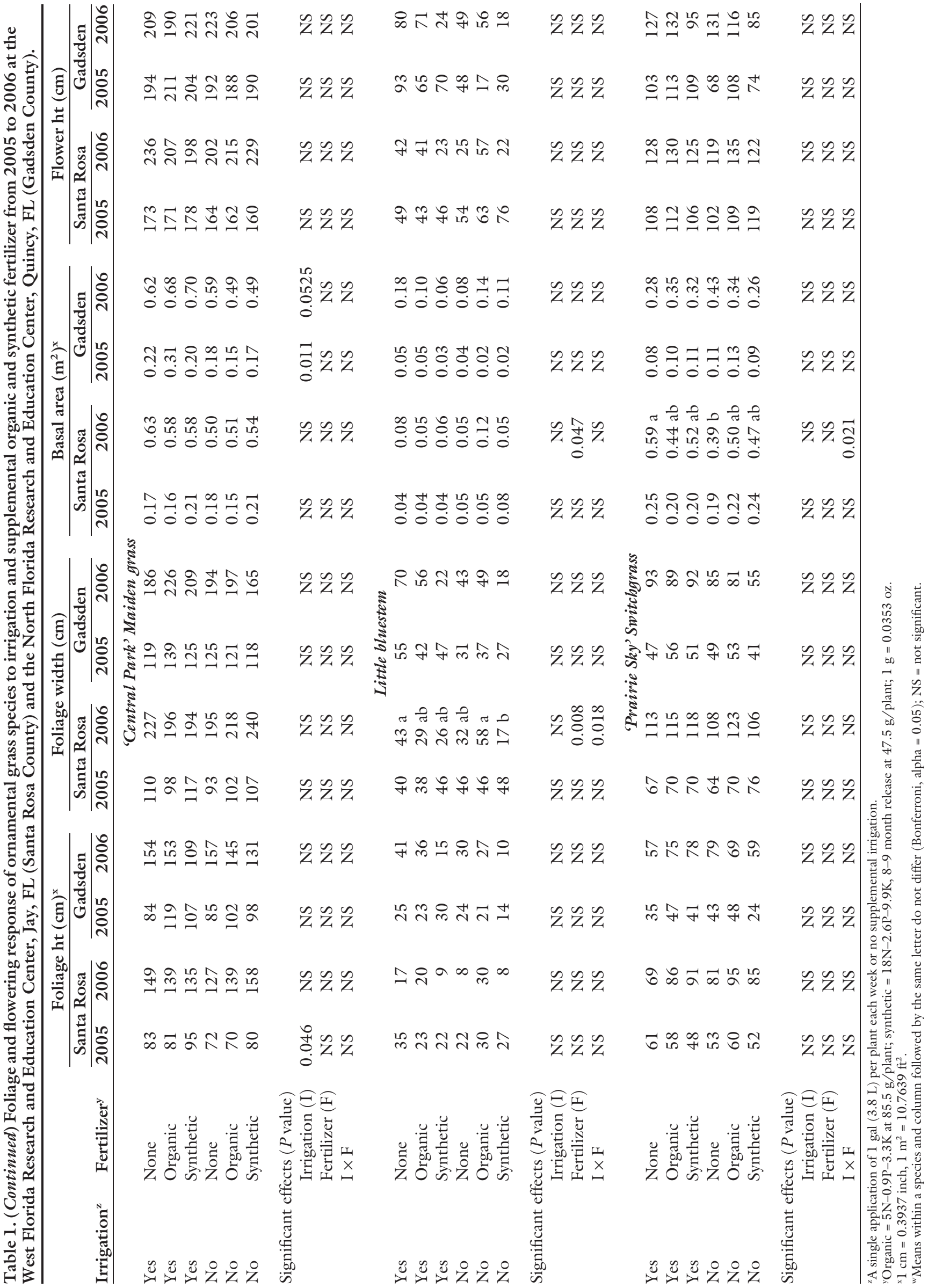




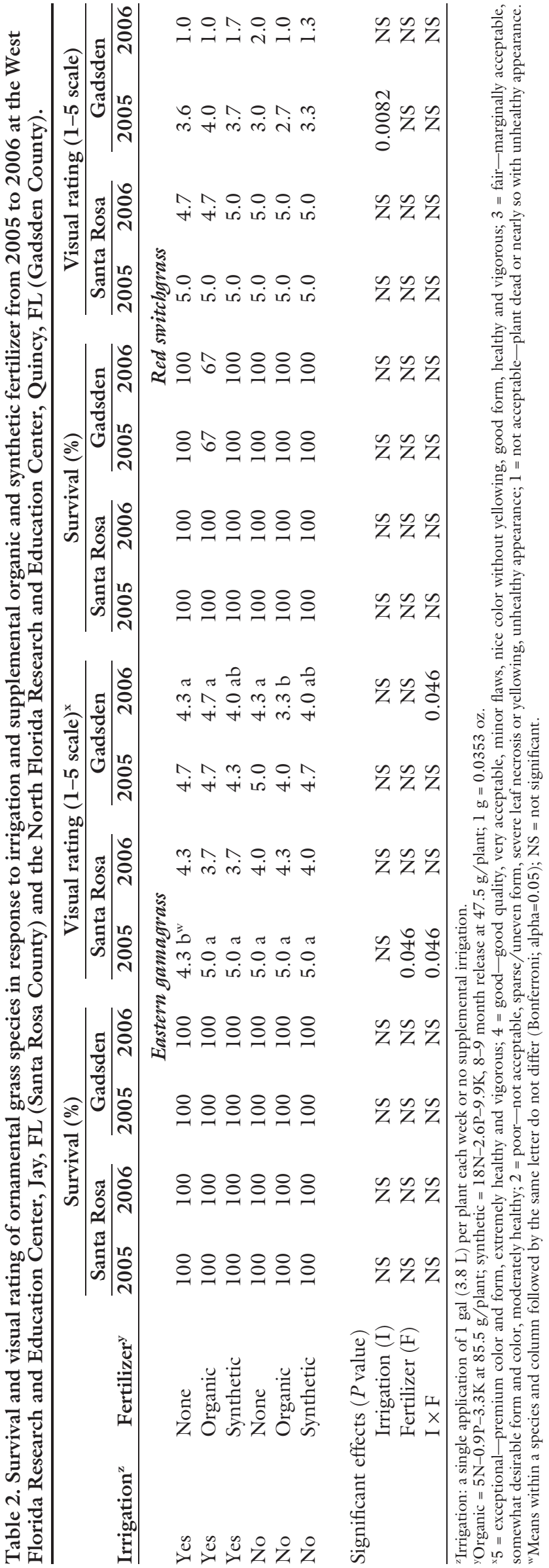

$0.16 \mathrm{~m}^{2}$ by the end of the second season with a mean foliage width of $126 \mathrm{~cm}$ and a mean foliage height of $66.4 \mathrm{~cm}$ in SRC. Plants in GC receiving supplemental irrigation had greater foliage width and basal area compared with plants receiving no supplemental irrigation in 2005. However, by the end of 2006 no differences were evident among irrigated and nonirrigated plants within each site, and plants in GC were generally larger than plants in SRC. Regardless of the differences in foliage width and flower height, visual rating scores were consistently high with a mean rating of 4.2 in 2006 indicating plants were of good to exceptional quality with nice form and color. The consistent high quality and high survival of this species concurs with prior investigations under conditions of natural rainfall over a 3-year period in Leon County, FL (LC) and SRC (Thetford et al., 2009).

'Adagio' maiden grass survival averaged $100 \%$ throughout the experiment. Supplemental irrigation and fertilization did not improve growth or performance. By the end of the second growing season plants had a mean foliage height of $87.7 \mathrm{~cm}$, foliage width of $179 \mathrm{~cm}$, and flower height averaged $146.8 \mathrm{~cm}$. There were no differences in visual ratings among the plants in response to irrigation or fertilization treatments. Plants in GC were initially rated higher than plants in SRC in 2005 although rating scores were similar among plants at both locations thereafter with a mean rating of 4.8 (data not shown).

'Central Park' maiden grass survival averaged $100 \%$ (data not shown) and there were no differences noted in foliage width $(204 \mathrm{~cm})$ or flower height $(197 \mathrm{~cm})$ regardless of location, irrigation or fertilization treatments (Table 1). No differences in foliage height were evident by 2006 although foliage height for plants in SRC was initially greater in 2005 for plants receiving supplemental irrigation. Basal area did not differ in SRC, whereas in GC plants receiving supplemental irrigation had greater basal area both years. Among all plants the mean visual quality rating averaged 4.5 indicating good to exceptional quality with plants in very acceptable condition, concurring with other Florida studies (Wilson and Knox, 2006).

The good to exceptional visual quality of these two maiden grass 
cultivars can be compared with growth and performance of other maiden grass cultivars within the same areas of Florida. Maiden grass evaluated in LC and SRC on similar Orangeburg sandy loam soils all performed better in SRC than in LC in the absence of supplemental irrigation (Thetford et al., 2009). Wilson and Knox (2006) grew maiden grass cultivars with subirrigation in southern Florida or drip irrigation in northern Florida (GC) and identified 'Adagio' and 'Central Park' as cultivars with good to excellent quality (plant color and form) although 'Central Park' had a narrower window of peak performance. Wilson and Knox (2006) also noted that maiden grass cultivars generally were larger in northern Florida than in southern Florida, produced more flowers and suggested such differences are related to the genus being better adapted to temperate rather than tropical climates. In the current trial, both locations are within a humid subtropical climate and temperatures for GC and SRC were relatively similar (Fig. 2). The lack of response to irrigation and nitrogen treatments was somewhat surprising since dry weight of maiden grass (Miscanthus xgiganteus) grown as a biomass crop has been shown to increase with nitrogen and irrigation (Ercoli et al., 1999). Nitrogen was more limiting to growth than water; even with irrigation growth was limited unless nitrogen was readily available.

Little bluestem survival averaged $86 \%$ in 2005 and $61 \%$ in 2006 (data not shown). Foliage height $(23 \mathrm{~cm})$ and flower height did not differ either year and differences in foliage width and basal area were evident in 2006 (Table 1). In SRC foliage width was influenced by fertilization and there was a fertilizer and irrigation interaction in 2006. With the addition of irrigation there was no difference in foliage width among fertilization treatments, whereas without supplemental irrigation foliage width of plants receiving organic fertilizer was greater than synthetic fertilizer. For basal area in 2006, there was no effect of irrigation but a significant effect of fertilizer where basal area for plants receiving organic or synthetic fertilizer differed $(P=0.0260)$ from each other but neither of these differed from plants receiving no fertilizer. In GC foliage, width and basal area generally increased over time although no differences were evident in response to fertilizer or irrigation. Despite the similarity in plant size at the two locations visual ratings for little bluestem were only fair (marginally acceptable) (3.0) in year 1 and by year 2 were rated as poor (2.6) with plants in GC rated lower than plants in SRC (Data not shown).

The lack of response of little bluestem to irrigation and fertilization was surprising considering the previous work by Kochsiek et al. (2006). Kochsiek et al. demonstrated that little bluestem responded positively to watering, but concluded a concurrent increase in fertilization would probably not provide any competitive advantage to this species. Under the conditions of our trials little bluestem did not show clear increases in growth in response to supplemental irrigation or fertilizer.

'Prairie Sky' switchgrass survival was not influenced by fertilization, irrigation, or planting location and overall survival averaged 97\% (data not shown). Foliage height and width and flower height did not differ in response to supplemental fertilization or irrigation (Table 1). However, differences in plant size and quality were evident between the two planting locations. Plants located in SRC had greater foliage height, foliage width, basal area, and inflorescence heights than plants in GC. Plants in SRC did show an interaction between fertilizer and irrigation in 2006 where plants receiving no fertilizer had a greater basal area with the addition of irrigation, but plants receiving fertilizer did not differ from those without fertilizer regardless of the addition of irrigation (Table 1). Visual ratings of 'Prairie Sky' switchgrass were below average in GC and above average in SRC although scores within a location did not differ significantly over the 2-year period (data not shown). Visual rating scores in GC decreased (reduced visual quality) (1.8 vs. 1.4 ), whereas visual rating scores in SRC increased (improved visual quality) (4.3 vs. 4.7) between 2005 and 2006.

Survival of red switchgrass averaged $97 \%$ over the 2 -year study (Table 2 ). Overall plants in SRC had a greater foliage height, foliage width, and basal area than plants in GC (Data not shown). Foliage height and basal area increased from 2005 to 2006 with mean height increasing from 54 to $78 \mathrm{~cm}$ and basal area increased from
0.1 to $0.5 \mathrm{~m}^{2}$. Within each location foliage width did not differ significantly over time with a mean foliage width of $128 \mathrm{~cm}$ in SRC and $87 \mathrm{~cm}$ in GC. Although overall differences in plant height and width were evident, all surviving plants produced inflorescences of similar height $(113 \mathrm{~cm})$. The visual rating for this species remained above average for plants in SRC (5.0), whereas the visual appearance of the plants in GC was fair in 2005 (3.4) when ratings for plants receiving irrigation were greater than for nonirrigated plants, but was below average in 2006 (1.3) regardless of irrigation or fertilizer treatments (Table 2).

Other studies have examined switchgrass biomass for feedstock production and shown an increased yield of biomass with increasing nitrogen rates up to $3 \mathrm{lb} / 1000 \mathrm{ft}^{2}$ applied in the spring (Madakadze et al., 1999) or at $3.4 \mathrm{lb} / 1000 \mathrm{ft}^{2}$ applied in April and June the following year (Muir et al., 2001) although no information on the visual quality of the crop was available. This pasture based work used different cultivars (Cave-in-Rock, Pathfinder, Sunburst, and Alamo) and is in contrast with this study and additional work conducted in simulated landscapes, which was more similar to our results. Proctor (2006) evaluated growth of 'Shenandoah' switchgrass in response to nitrogen rate and timing of application and reported no effect on growth index, top dry weight, visual evaluations, or initiation of flowering over a 2 -year period. Proctor reported a substantial increase in top dry weight between the two growing seasons of the experiment indicating sufficient nitrogen was available in the soil. The response of basal area of plants in SRC to both irrigation and fertilization in 2006 suggests that irrigation alone was sufficient to improve basal area, but where irrigation is absent potential exists to improve plant growth with the application of supplemental fertilizer.

\section{Conclusions}

Eastern gamagrass, elliott's lovegrass, gulf hairawn muhly, little bluestem, and 'Central Park' maiden grass showed a significant response to supplemental irrigation or fertilization. Supplemental irrigation did not influence foliage height for any of the grasses, whereas supplemental fertilization influenced foliage height only 
for chinese fountain grass. The differences noted between the two locations may be attributed in part to the differing soil types of the two sites. Generally soils of the two sites are described similarly as very deep, welldrained, with a moderate permeability. However the depth of the loamy sand for the Norfolk soil (A and E horizons) of GC is twice that of the Orangeburg soil (Ap horizon) of SRC, which also has a shallower B horizon with a higher clay content than the Norfolk soil. The deeper layer of loamy sand and deeper occurrence of the underlying loam and clay components would allow a greater drying of soil within the root zone of the grasses planted at GC compared with SRC. Soils of GC would have the potential to drain and dry more quickly between irrigation and rain events than soils of SRC which have loam and clay components located closer to the soil surface.

Previous ornamental and native grass landscape performance trials have demonstrated the potential to identify species or cultivars with a high level of survival and acceptable visual quality over a 3-year period without supplemental fertilizer or water (Thetford et al., 2009). This study observed minimal or no response of shoot growth to supplemental irrigation or fertilization for the grass species tested, thereby affirming broad adaptability and minimal need for inputs for these ornamental landscape plants. This study found a high level of survival and acceptable visual quality (mean rating of 3 or more) after two seasons for eastern gamagrass, elliot's lovegrass, gulf hairawn muhly, and 'Adagio' and 'Central Park' maiden grass in both sites and little bluestem and 'Prairie Sky' and red switchgrass in SRC. 'Hameln' chinese fountain grass was not an acceptable perennial in either site.

\section{Literature cited}

Davidson, C.G. and S.M. Gobin. 1998. Evaluation of ornamental grasses for the northern great plains. J. Environ. Hort. 16(4):218-229.

Ercoli, L., M. Mariotti, A. Masoni, and E. Bonari. 1999. Effect of irrigation and nitrogen fertilization on biomass yield and efficiency of energy use in crop production of Miscanthus. Field Crops Res. 63(1):3-11.

Gann, G.D., M.E. Abdo, J.W. Gann, G.D. Gann Sr., S.W. Woodmansee, K.A. Bradley, E. Verdon, and K.N. Hines. 2008. Natives for Your Neighborhood; Eragrostis elliottii. 17 June 2010. <http:// www.regionalconservation.org/beta/ nfyn/plantdetail.asp?tx=Eragelli $>$.

Greenlee, J. 1992. The encyclopedia of ornamental grasses: How to grow and use over 250 beautiful and versatile plants. Michael Friedman Publishing Group, New York.

Henson, J.F. and G.A. Fenchel. 2007. Plant guide: Eastern gamagrass Tripsacum dactyloides L. U.S. Dept. Agr., Natural Resource Conservation Serv., Natl. Plant Data Ctr., Baton Rouge, LA.

Kirk, S. and S. Belt. 2010. Plant fact sheet for hairawn muhly (Mublenbergia capillaris). U.S. Dept. Agr., Natural Resource Conservation Serv. In: Norman A (ed.). Berg Natl. Plant Materials Ctr., Beltstville, $\mathrm{MD}$.

Knox, G.W., T. Broschat, and R. Black (eds.). 2002. Fertilizer Recommendations for Landscape Plants. Univ. Florida., Inst. Food Agr. Sci. Fact Sheet ENH858. 10 June 2010. <http://edis.ifas.ufl.edu/ epl14>.
Kochsiek, A., V. Ciganda, N. Bryan, L. Hite, and T. Awada. 2006. Ecophysiological responses of Schizachyrium scoparium to water and nitrogen manipulations. Great Plains Res. 16(1):29-36.

Madakadze, I.C., K.A. Stewart, R.R. Peterson, B.E. Coulman, and D.L. Smith. 1999. Cutting frequency and nitrogen fertilization effects on yield and nitrogen concentration of switchgrass in a short season area. Crop Sci. 39(2):552-557.

Muir, J.P., M.A. Sanderson, W.R. Ocumpaugh, R.M. Jones, and R.L. Reed. 2001. Biomass production of 'Alamo' switchgrass in response to nitrogen, phosphorus, and row spacing. Agron. J. 93(4):896-901.

Proctor, C.L. 2006. Effect of fertilizer nitrogen rate and timing on growth and performance of six herbaceous perennials and soil solution nitrogen concentration in a simulated landscape. North Carolina State Univ., Raleigh, MS Thesis.

Robinson, M.L. and U.E. Schultz. 1994. New introductions of drought tolerant plant materials for parking lots and highway medians. Proc. Florida State Hort. Soc. 107:194-196.

Thetford, M., J.G. Norcini, B. Ballard, and J.H. Aldrich. 2009. Ornamental landscape performance of native and nonnative grasses under low-input conditions. HortTechnology 19:267-285.

Wilson, S.B. and G.W. Knox. 2006. Landscape performance, flowering, and seed viability of 15 japanese silver grass cultivars grown in northern and southern Florida. HortTechnology 16:1-8.

Wilson, S.B. and G.W. Knox. 2009. Landscape performance of green fountain grass alternatives grown in northern and southern Florida. HortTechnology 19: 471-476. 